\title{
Problematyka badań niezawodności wagonów osobowych na tle stanu badań niezawodności pojazdów szynowych w Polsce
}

\begin{abstract}
W pracy przedstawiono ocene stanu badań niezawodności (w systemie eksploatacji technicznej) pojazdów szynowych, ze szczególnym uwzględnieniem problematyki niezawodności wagonów osobowych. Ocenie poddano prace drukowane na tamach wybranych czasopism oraz w materiałach wybranych konferencji naukowych w latach 1972 $\div 2003$. Zestawiono prace wzięte do analizy. Podano charakterystykę materiału badawczego. Wskazano na zainteresowania w badaniach niezawodności kolejnymi fazami życia pojazdów szynowych. Dokonano przegladu prac i przeprowadzono syntetycznq ocenę ich treści. Przedstawiono charakterystykę autorów prac poddanych analizie.
\end{abstract}

\section{Wprowadzenie}

W latach 50-tych XX wieku zgodzono się, że obiekty, procesy, systemy - oprócz wielu cech ilościowych mają cechę (właściwość), która nazywa się: „niezawodność" (,reliability” - po angielsku, „Zuverlässigkeit” - po niemiecku, ,fiabilitée - po francusku, „,nadiożnost" - po rosyjsku). Na początku lat siedemdziesiątych zaczyna gruntować swoją pozycję teoria niezawodności. Dziś po ponad trzydziestu latach aplikacji teorii niezawodności w różnych dziedzinach życia i na różnych etapach istnienia obiektów / systemów technicznych, zasadnym jest podjęcie próby oceny stanu badań niezawodności obiektów / systemów funkcjonujących w ramach systemu eksploatacji technicznej pojazdów szynowych (SETPSz). W skład systemu eksploatacji technicznej pojazdów szynowych wchodzi m.in. system eksploatacji technicznej wagonów osobowych (SETWO). System eksploatacji technicznej pojazdów szynowych jest częścią systemu transportu kolejowego.

Celem niniejszego opracowania jest prezentacja zainteresowania problemami niezawodności wagonów osobowych na tle stanu badań niezawodności pojazdów szynowych w Polsce.

\section{Metodyka dokonywania oceny}

Ocenę stanu badań niezawodności obiektów SETPSz i SETWO oparto na pracach opublikowanych $w$ czasopismach:

- „Pojazdy Szynowe”,

- „Zagadnienia Eksploatacji Maszyn”,

- „Problemy Kolejnictwa”,

- „Trakcja i Wagony”,

- "Technika Transportu Szynowego",

- „Przegląd Kolejowy”,

- „Zeszyty Naukowe Politechniki Poznańskiej, seria MRiT",

oraz na referatach opublikowanych w materiałach następujących konferencji:

- „Pojazdy Szynowe”,

- „Problemy Niezawodności Transportu”,

- „Zimowa Szkoła Niezawodności”,

- „Konferencja Bezpieczeństwa i Niezawodności”.
Czasopismo "Pojazdy Szynowe" zainicjowane zostało numerem specjalnym w 1975 roku. Od 1976 roku do czerwca 1981 "Pojazdy Szynowe" ukazywały się systematycznie. Po kilkuletniej przerwie, w roku 1998 czasopismo to zaczęło się ponownie ukazywać. Wydawca „Pojazdów Szynowych” jest Instytut Pojazdów Szynowych „TABOR” w Poznaniu.

Kwartalnik Polskiej Akademii Nauk „Zagadnienia Eksploatacji Maszyn" zaczął się ukazywać w 1966 roku. Do roku 1973 kwartalnik ten wydawany był pod nazwą „Zagadnienia Tarcia, Zużycia i Smarowania”. Wydawca „Zagadnień Eksploatacji Maszyn” są Państwowe Wydawnictwa Naukowe.

W 1956 roku Centralny Ośrodek Badań i Rozwoju Techniki Kolejnictwa wydał pierwszy numer czasopisma „Problemy Kolejnictwa”. Do końca roku 2003 ukazało się 135 zeszytów „Problemów Kolejnictwa”.

Kolejnym czasopismem, z którego materiałów skorzystano w niniejszej pracy jest miesięcznik wydawany przez Wydawnictwa Komunikacji i Łączności pod nazwa „Trakcja i Wagony”. Pierwszy numer tego czasopisma ukazał się w 1978 roku. Czasopismo przestało ukazywać się w 1991 roku. Kontynuacją „Trakcji i Wagonów” jest miesięcznik „Przeglad Kolejowy”. Ukazywal się on od lipca 1992 roku do marca 2001 roku nakładem Kolejowej Oficyny Wydawniczej Spółka z o. o..

Czasopismo "Technika Transportu Szynowego" (TTS) stanowi m.in. forum dla prezentacji problemów produkcji i eksploatacji pojazdów szynowych. Pierwszy numer tego czasopisma ukazał się w czerwcu 1994 roku. Patronat nad TTS sprawuje Stowarzyszenie Inżynierów i Techników Komunikacji RP (SITK) - członek Unii Europejskich Stowarzyszeń Inżynierów Kolejowych UEEIV.

„Zeszyty Naukowe Politechniki Poznańskiej, seria MRiT" ukazują się od 1956 roku. Do roku 1969 ukazywały się pod nazwą „Mechanizacja i Elektryfikacja Rolnictwa”, następnie pod nazwą „Zeszyty Naukowe Politechniki Poznańskiej, seria MRiP". Do końca roku 2003 ukazało się 57 zeszytów. 
Konferencje „Pojazdy Szynowe” zostały zainicjowane w 1973 roku. Do końca 2003 roku środowiska naukowoprzemysłowe, którym bliskie są zagadnienia szeroko pojętego projektowania, wytwarzania i eksploatacji pojazdów szynowych - zorganizowały piętnaście edycji tej konferencji.

Na sesjach naukowych „Problemów Niezawodności Transportu" prezentowane były zagadnienia niezawodności transportu lotniczego, samochodowego, kolejowego i morskiego. Początek tych sesji przypada na rok 1980. W roku 1997 odbyła się ostatnia edycja „Problemów Niezawodności Transportu".

„Konferencję Bezpieczeństwa i Niezawodności" (KONBiN) zainicjowano w 1999 roku. Jest ona spadkobiercą połączonej problematyki konferencji „Problemy Niezawodności Transportu” i „Bezpieczeństwo Systemów”.

Organizatorem "Zimowych Szkót Niezawodności” jest Zespół Niezawodności Sekcji Podstaw Eksploatacji Komitetu Budowy Maszyn PAN. Spotkania z tego cyklu rozpoczęto w 1972 roku. W styczniu 2003 roku odbyła się XXXI Zimowa Szkoła Niezawodności. Problematyka Szkół dotyczy niezawodności elementów zespołów, maszyn, urządzeń i pojazdów, parków maszynowych i dużych systemów technicznych.

W wymienionych czasopismach i w materiałach wskazanych tu konferencji, zagadnieniom niezawodności obiektów / systemów, związanych z systemem eksploatacji technicznej pojazdów szynowych poświęcono 120 prac. Dziewiętnaście $\mathrm{z}$ nich związanych jest $\mathrm{z}$ zagadnieniami niezawodności wagonów osobowych.

Oceny prezentowanych $\mathrm{w}$ tych pracach zagadnień dokonano za pomocą specjalnego arkusza badawczego. Układ i prezentację graficzną arkusza badawczego przedstawiono na rys. 1 i 2 . Za pomocą tego arkusza dokonywano oceny prac przez udzielanie odpowiedzi na 12 pytań. Strukturę zbioru prac poddanych analizom przedstawiono na rys. 3. W następnej kolejności informacje zgromadzone w arkuszach badawczych wprowadzono do specjalnie stworzonej bazy danych. Na podstawie zapytań (kwerend) przygotowanych do bazy danych wygenerowano wyniki oceny. W dalszej części niniejszego opracowania przedstawiono wybrane wyniki oceny badań obiektów / systemów, funkcjonujących w ramach systemu eksploatacji technicznej pojazdów szynowych.

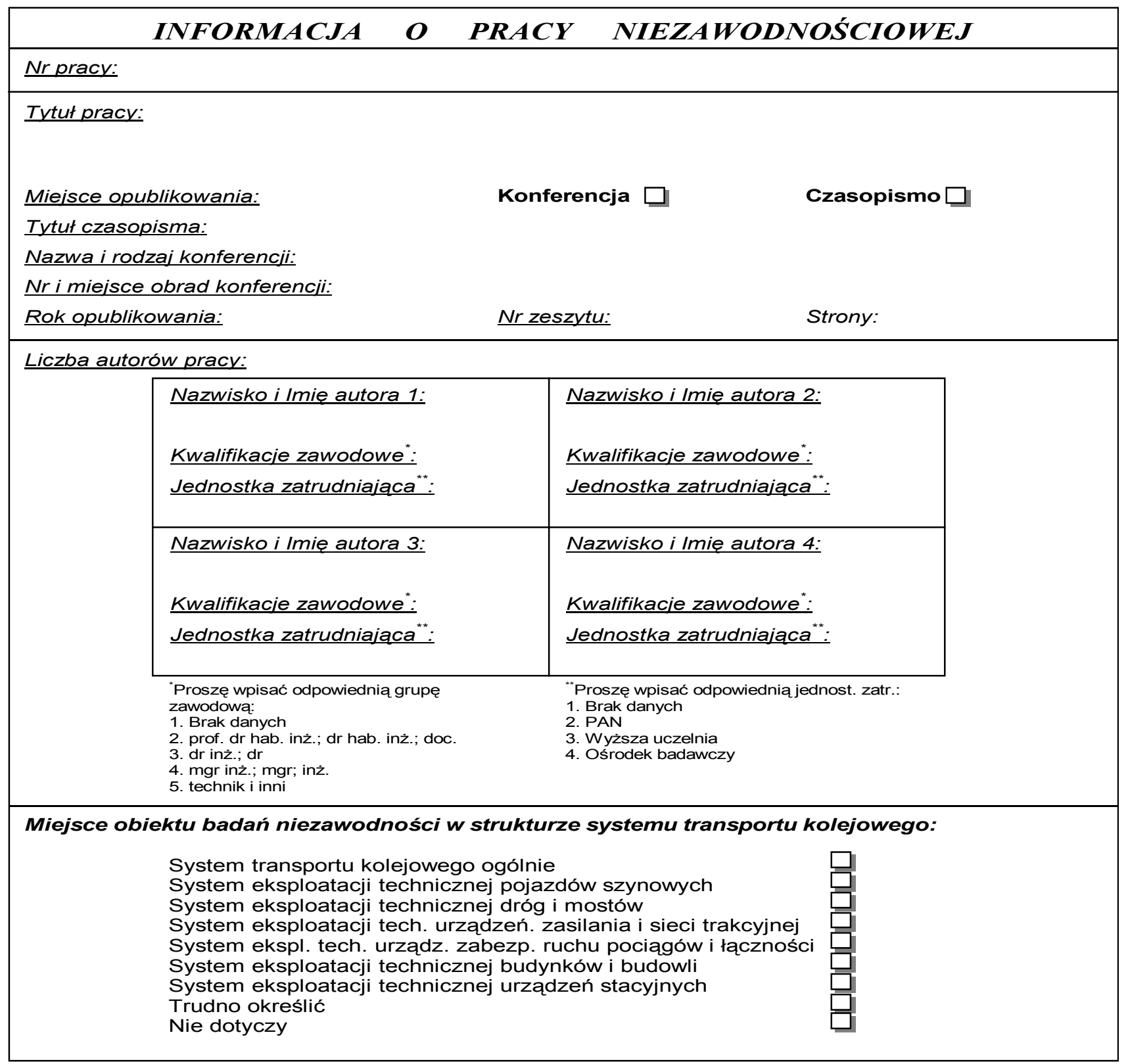

Rys. 1. Arkusz badawczy prac - strona 1 


\begin{tabular}{|c|c|c|c|}
\hline & INFORMACJA & $\boldsymbol{P R} \boldsymbol{A C Y}$ & NIEZAWODNOŚCIOWEJ \\
\hline \multicolumn{4}{|c|}{ Określenie obiektu badań: } \\
\hline \multicolumn{3}{|c|}{$\begin{array}{l}\text { System obiektów } \\
\text { System i pojedyncze obiekty }\end{array}$} & $\begin{array}{l}\text { Pojedyncze obiekty } \\
\text { Trudno określić }\end{array}$ \\
\hline \multicolumn{4}{|c|}{ Obiekt badań w systemie eksploatacji technicznej pojazdów szynowych: } \\
\hline \multicolumn{3}{|c|}{$\begin{array}{l}\text { Lokomotywy elektryczne i ezt } \\
\text { Lokomotywy spalinowe } \\
\text { Wagony osobowe }\end{array}$} & $\begin{array}{l}\text { Wagony towarowe } \\
\text { Maszyny torowe } \\
\text { Nie dotyczy }\end{array}$ \\
\hline \multicolumn{4}{|c|}{ Określenie etapu istnienia obiektu / systemu będącego przedmiotem prezentacji: } \\
\hline \multicolumn{4}{|c|}{$\begin{array}{l}\text { Etap koncepcji obiektu lub systemu } \\
\text { Etap konstrukcji obiektu lub planowania systemu } \\
\text { Etap wytwarzania obiektu lub wdrażania systemu } \\
\text { Etap eksploatacji obiektu lub funkcjonowania systemu } \\
\text { Trudno określić }\end{array}$} \\
\hline \multicolumn{4}{|c|}{$\begin{array}{l}\text { Szczegółowe określenie obiektu badań w systemie eksploatacji technicznej pojazdów } \\
\text { szynowych: }\end{array}$} \\
\hline$x^{2}$ & $\begin{array}{l}\text { Cały pojazd szynowy } \\
\text { Silnik spalinowy } \\
\text { Urządzenia pomocnicze } \\
\text { Rama wózka z osprzętem } \\
\text { Elektryczny silnik trakcyjny }\end{array}$ & $\begin{array}{l}\square \\
\square \\
\square \\
\square\end{array}$ & $\begin{array}{l}\text { Zestaw kołowy } \\
\text { Urządzenia zderzne i cięgłowe } \square \\
\text { Wyposażenie elektryczne } \\
\text { Nie dotyczy } \\
\text { Inne:................................... }\end{array}$ \\
\hline \multicolumn{4}{|c|}{ Określenie zawartości pracy: } \\
\hline \multicolumn{4}{|c|}{$\begin{array}{l}\text { Opis pewnej sytuacji lub koncepcji metody } \\
\text { Opis przeprowadzonych badań } \\
\text { Modele heurystyczne } \\
\text { Rozwiązania modeli heurystycznych } \\
\text { Modele analityczne } \\
\text { Rozwiązania modeli analitycznych } \\
\text { Modele symulacyjne } \\
\text { Eksperymenty symulacyjne } \\
\text { Modele optymalizacyjne } \\
\text { Eksperymenty optymalizacyjne } \\
\text { Dydaktyka w niezawodności } \\
\text { System informatyczny } \\
\text { Wyniki przeprowadzonych badań }- \text { statystyka opisowa } \\
\text { Wyniki przeprowadzonych badań }- \text { charakterystyki niezawodnościowe } \\
\text { Formułowanie postulatów niezawodnościowych } \\
\text { Inne:............................................................................................. }\end{array}$} \\
\hline Uwagi: & & & \\
\hline
\end{tabular}

Rys. 2. Arkusz badawczy prac - strona 2

\section{Wyniki badań}

\subsection{Rozkład w czasie kalendarzowym zainteresowań} problematyką badań niezawodności

Pierwsze prace związane z problemami niezawodności obiektów systemu eksploatacji technicznej pojazdów szynowych opublikowano w roku 1972, natomiast pierwsze prace dotyczące wagonów osobowych ukazały się w 1977 roku. Intensywność pojawiania się publikacji w czasie kalendarzowym charakteryzują rozkłady przedstawione na rys. 4 i 5. Wynika z nich, że najwięcej prac poświęconych niezawodności obiektów systemu eksploatacji technicznej

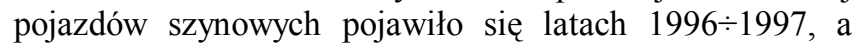
największa liczba prac związanych tematycznie z wagonami osobowymi ukazała się w latach $1979 \div 1980$.
Autorzy prac poddanych analizie interesowali się różnymi etapami istnienia obiektów lub systemów. Stan faktyczny tych badań przedstawiono w tabelach 1 i 2 oraz na rys. 6.

Systemowi eksploatacji technicznej pojazdów szynowych poświęcono 120 prac spośród wymienionych w spisie literatury. Najwięcej $\mathrm{z}$ nich bo aż $74,38 \%$ (rys. 6) porusza zagadnienia związane $\mathrm{z}$ etapem eksploatacji obiektów lub funkcjonowaniem systemów. Największa liczba prac $\mathrm{z}$ tego zakresu powstała w latach $1978 \div 1979$ i $1988 \div 1991$ (tabela 1). Tylko jedna praca została poświęcona zagadnieniom niezawodności na etapie wytwarzania obiektów lub wdrażania systemów. 


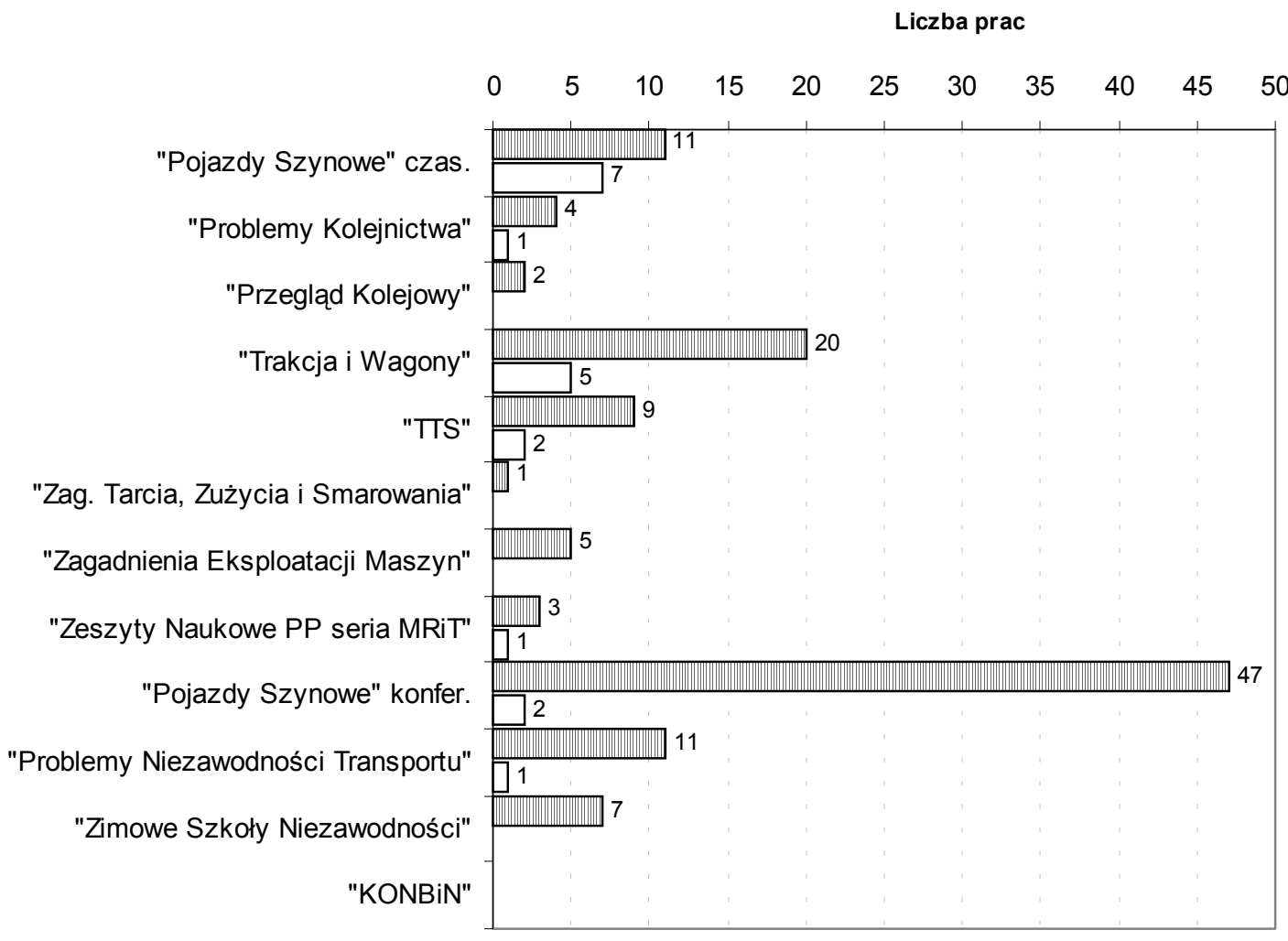

四Obiekty systemu ekspl. tech. poj. szyn. (SETPSZ)

$\square$ Obiekty systemu ekspl. tech. wag. osob. (SETWO)

Rys. 3. Struktura zbioru prac poddanych analizom a poświęconych problematyce niezawodności obiektów systemu eksploatacji technicznej pojazdów szynowych

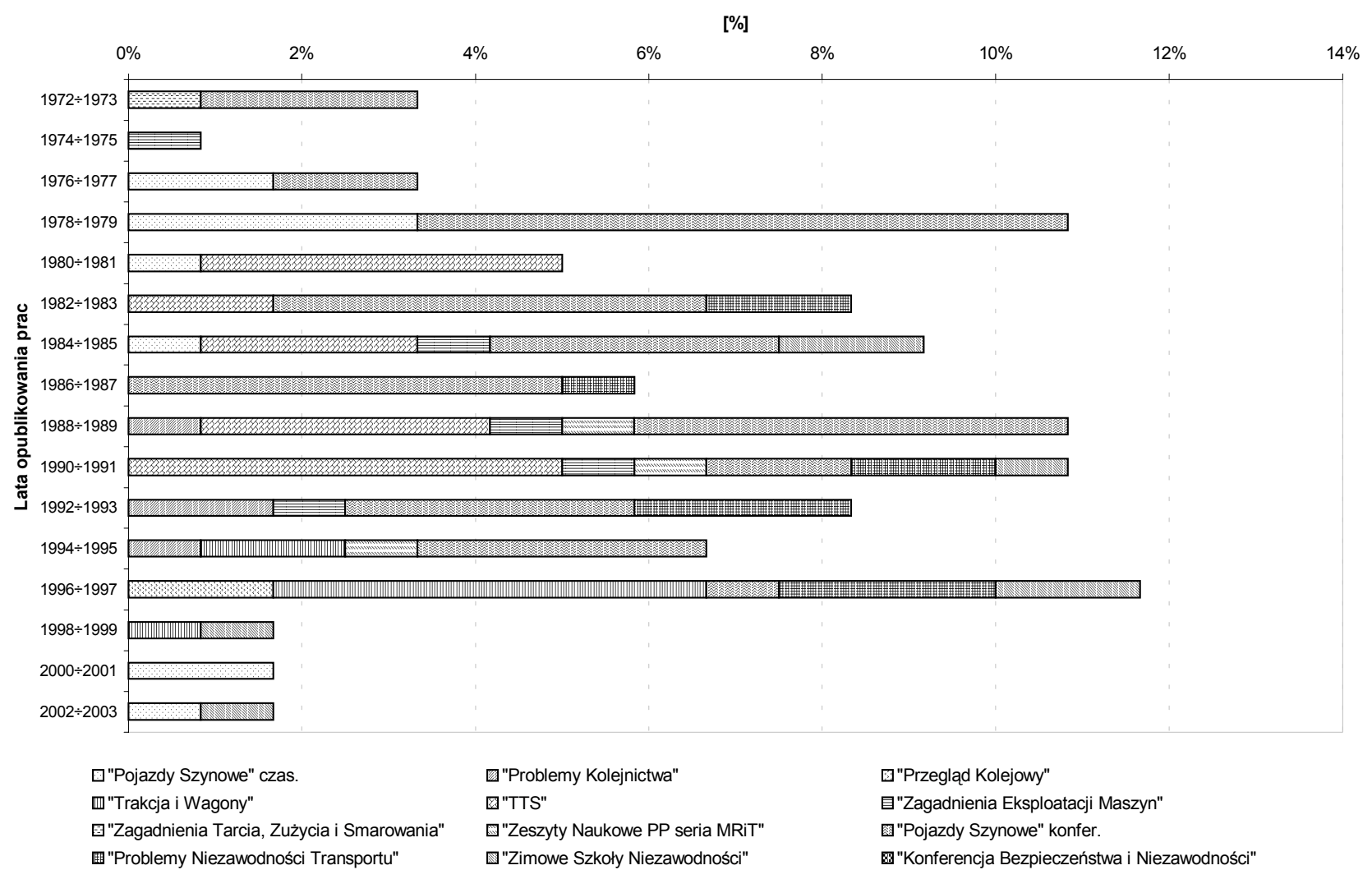

Rys. 4. Rozkład w czasie kalendarzowym opublikowania prac poddanych analizom a poświęconych problematyce niezawodności obiektów systemu eksploatacji technicznej pojazdów szynowych z uwzględnieniem nazw czasopism i konferencji 
[\%]

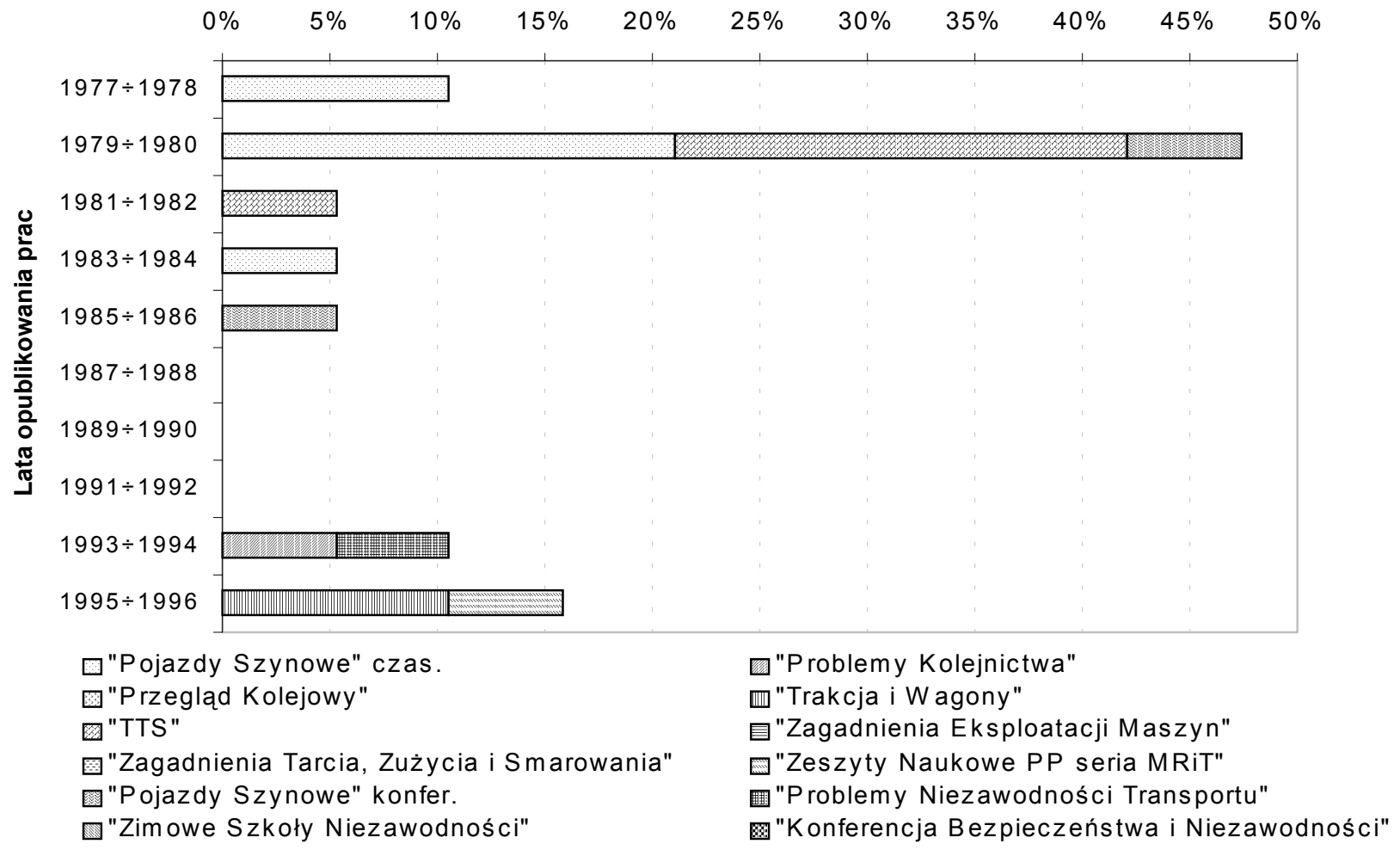

Rys. 5. Rozkład w czasie kalendarzowym opublikowania prac poddanych analizom a poświęconych badaniom niezawodności wagonów osobowych z uwzględnieniem nazw czasopism i konferencji

Ocena stanu zainteresowania autorów badaniami niezawodności systemów / obiektów na różnych etapach ich istnienia w ramach systemu eksploatacji technicznej pojazdów szynowych według lat opublikowania prac

Tabela 1

\begin{tabular}{|c|c|c|c|c|c|c|}
\hline \multirow{2}{*}{$\begin{array}{c}\text { Przedział lat } \\
\text { opublikowania prac }\end{array}$} & \multicolumn{5}{|c|}{$\begin{array}{c}\text { Liczba prac według etapu istnienia systemu lub obiektu } \\
\text { (znaczenie oznaczeń 1,2,.,5 podano pod tablica) }\end{array}$} \\
\cline { 2 - 7 } & 1 & 2 & 3 & 4 & 5 & Łacznie \\
\hline $1972 \div 1973$ & 0 & 1 & 0 & 3 & 0 & 4 \\
$1974 \div 1975$ & 0 & 0 & 0 & 1 & 0 & 1 \\
$1976 \div 1977$ & 0 & 0 & 0 & 4 & 0 & 4 \\
$1978 \div 1979$ & 0 & 1 & 0 & 12 & 0 & 13 \\
$1980 \div 1981$ & 0 & 0 & 0 & 5 & 1 & 6 \\
$1982 \div 1983$ & 0 & 1 & 1 & 8 & 0 & 10 \\
$1984 \div 1985$ & 1 & 3 & 0 & 7 & 0 & 11 \\
$1986 \div 1987$ & 1 & 2 & 0 & 4 & 0 & 7 \\
$1988 \div 1989$ & 0 & 3 & 0 & 10 & 0 & 13 \\
$1990 \div 1991$ & 0 & 3 & 0 & 10 & 0 & 13 \\
$1992 \div 1993$ & 2 & 2 & 0 & 6 & 0 & 10 \\
$1994 \div 1995$ & 0 & 2 & 0 & 6 & 0 & 8 \\
$1996 \div 1997$ & 0 & 4 & 0 & 9 & 1 & 14 \\
$1998 \div 1999$ & 0 & 0 & 0 & 1 & 1 & 2 \\
$2000 \div 2001$ & 1 & 0 & 0 & 1 & 0 & 2 \\
$2002 \div 2003$ & 0 & 0 & 0 & 2 & 0 & 2 \\
\hline Ogółem & 5 & 22 & 1 & 89 & 3 & 120 \\
\hline
\end{tabular}

1. Etap koncepcji obiektu lub systemu

2. Etap konstrukcji obiektu lub planowania systemu

3. Etap wytwarzania obiektu lub wdrażania systemu

4. Etap eksploatacji obiektu lub funkcjonowania systemu

5. Trudno określić 
Podobnie jak w obszarze badawczym systemu eksploatacji technicznej pojazdów szynowych, tak i w przypadku obszaru badawczego systemu eksploatacji technicznej wagonów osobowych znaczna część prac poświęcona jest etapowi eksploatacji obiektów $(78,95 \%)$.
Największa liczba prac z tego zakresu powstała w latach $1979 \div 1980$ (tabela 2). W przypadku wagonów osobowych nie powstała ani jedna praca poświęcona zagadnieniom niezawodności na etapie koncepcji obiektu.

\section{Ocena stanu zainteresowania autorów badaniami niezawodności wagonów osobowych na}

różnych etapach ich istnienia według lat opublikowania prac

Tabela 2

\begin{tabular}{|c|c|c|c|c|c|c|}
\hline \multirow{2}{*}{$\begin{array}{c}\text { Przedział lat } \\
\text { opublikowania prac }\end{array}$} & \multicolumn{5}{|c|}{$\begin{array}{c}\text { Liczba prac według etapu istnienia systemu lub obiektu } \\
\text { (znaczenie oznaczen } 1,2, \ldots, 5 \text { podano pod tablica) }\end{array}$} \\
\cline { 2 - 7 } & 1 & 2 & 3 & 4 & 5 & Lacznie \\
\hline $1977 \div 1978$ & 0 & 0 & 0 & 2 & 0 & 2 \\
$1979 \div 1980$ & 0 & 0 & 0 & 8 & 1 & 9 \\
$1981 \div 1982$ & 0 & 0 & 1 & 0 & 0 & 1 \\
$1983 \div 1984$ & 0 & 0 & 0 & 1 & 0 & 1 \\
$1985 \div 1986$ & 0 & 0 & 0 & 1 & 0 & 1 \\
$1987 \div 1988$ & 0 & 0 & 0 & 0 & 0 & 0 \\
$1989 \div 1990$ & 0 & 0 & 0 & 0 & 0 & 0 \\
$1991 \div 1992$ & 0 & 0 & 0 & 0 & 0 & 0 \\
$1993 \div 1994$ & 0 & 0 & 0 & 2 & 0 & 2 \\
$1995 \div 1996$ & 0 & 2 & 0 & 1 & 0 & 3 \\
\hline Ogółem & 0 & 2 & 1 & 15 & 1 & 19 \\
\hline
\end{tabular}

1. Etap koncepcji obiektu lub systemu

2. Etap konstrukcji obiektu lub planowania systemu

3. Etap wytwarzania obiektu lub wdrażania systemu

4. Etap eksploatacji obiektu lub funkcjonowania systemu

5. Trudno określić

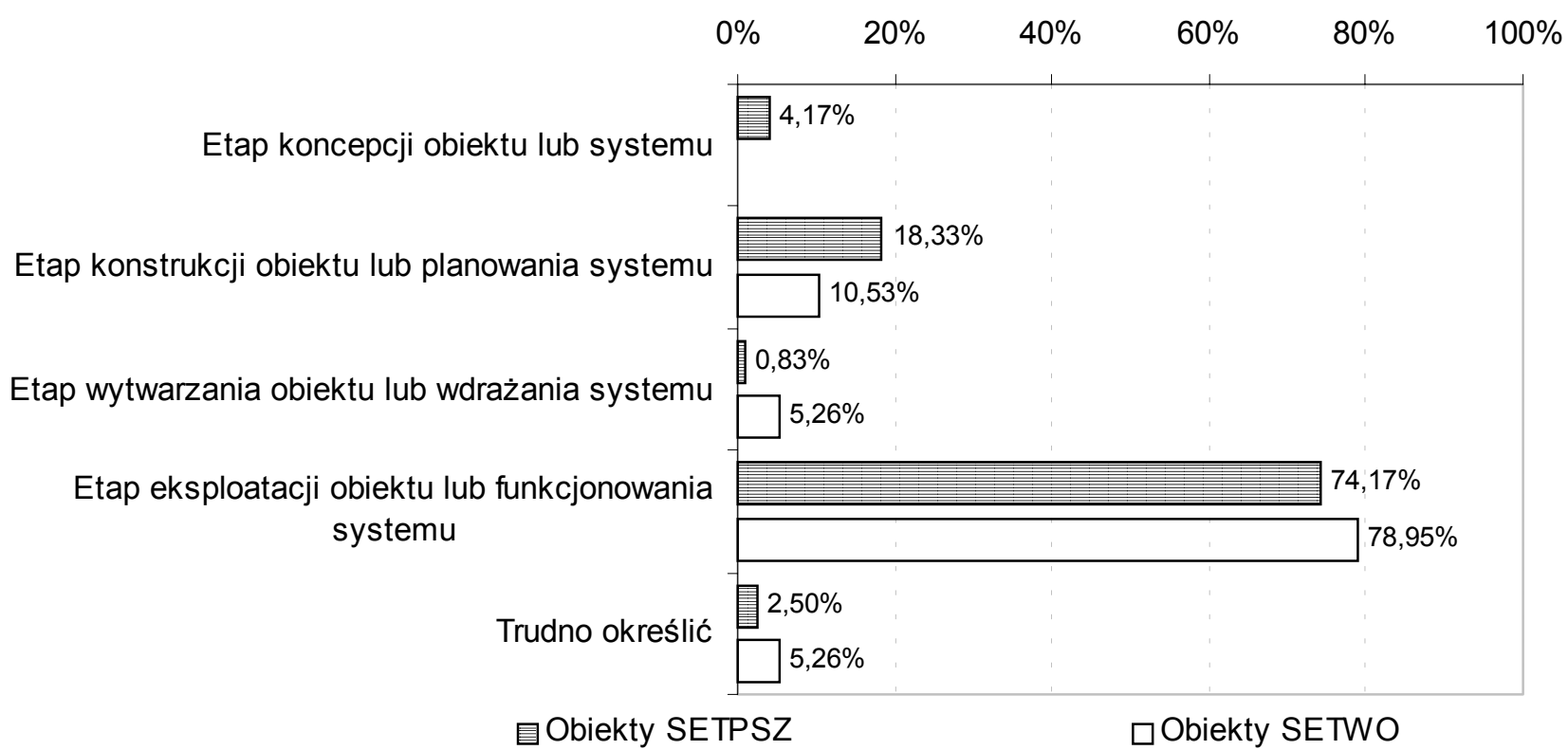

Rys. 6. Histogram oceny stanu zainteresowania autorów etapami istnienia systemów / obiektów w zakresie badań niezawodnościowych w ramach systemu eksploatacji technicznej pojazdów szynowych i wagonów osobowych 


\subsection{Syntetyczna ocena treści prac}

W celu syntetycznego opisu treści prac poświęconych zagadnieniom niezawodności w systemie eksploatacji technicznej pojazdów szynowych, dokonano ich oceny według 16 kryteriów umieszczonych w arkuszu badawczym (rys. 2). Wyniki tej oceny zawiera tabela 3 oraz rys. 7. Umieszczono w niej zestawienie określeń zawartości pracy (kryteriów oceny), wyniki oceny ilościowej dokonanej według tych kryteriów oraz wykaz prac (wykorzystując numery nadane im w spisie literatury), których tematyka mieściła się w obszarze wskazywanym przez kryteria. Dodatkowo prace mieszczące się w obszarze systemu eksploatacji technicznej wagonów osobowych - podkreślono (tabela 3).

\section{Wyniki oceny treści prac poświęconych problemom niezawodnościowych badań obiektów systemu eksploatacji pojazdów szynowych}

Tabela 3

\begin{tabular}{|c|c|c|c|}
\hline Określenie zawartości & \multicolumn{2}{|c|}{ Liczba prac } & \multirow{2}{*}{$\begin{array}{l}\text { Wykaz prac według numerów } \\
\text { przyporządkowanych w spisie literatury }\end{array}$} \\
\hline pracy & {$[-]$} & {$[\%]$} & \\
\hline$-1-$ & $-2-$ & $-3-$ & $-4-$ \\
\hline \multirow{2}{*}{$\begin{array}{l}\text { Opis pewnej sytuacji lub koncepcji } \\
\text { metody }\end{array}$} & 53 & 44,17 & \multirow{2}{*}{$\begin{array}{l}{[1,3,4,5,6,7,11,12,19,20, \underline{22}, 24,26,28,30,31,32,34,35,} \\
36,42,43,44,45,48,49,50,52,53,54,55,57, \\
61,63,81,84, \\
87, \underline{88}, \underline{89}, 92,93, \underline{99}, \underline{100}, 102,103,105,108,111, \underline{112}, \underline{114}, \\
115, \underline{119}, \underline{120}]\end{array}$} \\
\hline & $\underline{10}$ & $\underline{52,63}$ & \\
\hline \multirow[t]{3}{*}{ Opis przeprowadzonych badań } & & & \multirow{3}{*}{$\begin{array}{l}{[1,8,10,11,13,14,15,16,17,25,27,31,36, \underline{37}, 38,39,40,41} \\
, 47,51,56,61,64,65,66,67, \underline{68}, 69,70,71,72,73,76,77,78, \\
79,80,83,84,91,95,96,97,98,101,103,106, \\
107,109,110, \\
\underline{112}, \underline{114}, \underline{115}, 118, \underline{119}, \underline{121}, 122]\end{array}$} \\
\hline & 58 & 47,50 & \\
\hline & $\underline{7}$ & $\underline{36,84}$ & \\
\hline \multirow[t]{2}{*}{ Modele heurystyczne } & 0 & 0,00 & \multirow{2}{*}{----} \\
\hline & 0 & 0,00 & \\
\hline \multirow{2}{*}{$\begin{array}{l}\text { Rozwiazzania modeli } \\
\text { heurystycznych }\end{array}$} & 0 & 0,00 & \multirow{2}{*}{----- } \\
\hline & $\underline{0}$ & $\underline{0,00}$ & \\
\hline \multirow[t]{2}{*}{ Modele analityczne } & 32 & 25,83 & \multirow{2}{*}{$\begin{array}{l}{[4,6,7,10,17,21, \underline{22}, 27,32,34,35,41,42,43,44,51,52,58,} \\
\underline{59}, 69,85,86, \underline{88}, 97, \underline{99}, 102,106,113, \underline{112}, \underline{115}, \underline{117}]\end{array}$} \\
\hline & $\underline{7}$ & 36,84 & \\
\hline \multirow[t]{2}{*}{ Rozwiązania modeli analitycznych } & 19 & 15,00 & \multirow{2}{*}{$\begin{array}{l}{[6,10,17,21,27,42,44,51,58,69,85,86, \underline{88}, 97, \underline{99}, 106,} \\
\underline{112}, \underline{117]}\end{array}$} \\
\hline & $\underline{4}$ & 21,05 & \\
\hline \multirow[t]{2}{*}{ Modele symulacyjne } & 13 & 10,83 & \multirow{2}{*}[7,20,21,23,24,25,26,27,28,31,32,35,78]{} \\
\hline & $\underline{0}$ & $\underline{0,00}$ & \\
\hline \multirow[t]{2}{*}{ Eksperymenty symulacyjne } & 13 & 10,83 & \multirow{2}{*}[7,20,21,\underline{22},24,25,26,27,28,31,32,35,78]{} \\
\hline & $\underline{1}$ & $\underline{5,26}$ & \\
\hline \multirow[t]{2}{*}{ Modele optymalizacyjne } & 2 & 1,67 & \multirow{2}{*}[26,35]{} \\
\hline & $\underline{0}$ & $\underline{0,00}$ & \\
\hline \multirow[t]{2}{*}{ Eksperymenty optymalizacyjne } & 2 & $\overline{1,67}$ & \multirow{2}{*}[26,35]{} \\
\hline & $\underline{0}$ & $\underline{0,00}$ & \\
\hline \multirow[t]{2}{*}{ Dydaktyka w niezawodności } & 1 & 0,83 & \multirow{2}{*}{ [23] } \\
\hline & $\underline{0}$ & $\underline{0,00}$ & \\
\hline \multirow[t]{2}{*}{ System informatyczny } & 6 & 5,00 & \multirow{2}{*}[\underline{22},34,81,82,103,105]{} \\
\hline & $\underline{1}$ & $\underline{5,26}$ & \\
\hline \multirow[t]{2}{*}{ Wyniki - statystyka opisowa } & 44 & 36,67 & \multirow{2}{*}{$\begin{array}{l}{[8,14,15,16, \underline{18}, 19,36, \underline{37}, 39,40,46,47,50,56,60,61,65,} \\
66,67, \underline{68}, 69,70,77,79,80,81,84,85,90,91,98,101,107, \\
109,110, \underline{11}, \underline{113}, \underline{114}, \underline{115}, \underline{116}, 118, \underline{119}, \underline{120}, \underline{121}]\end{array}$} \\
\hline & $\underline{11}$ & $\underline{57,89}$ & \\
\hline \multirow{2}{*}{$\begin{array}{l}\text { Wyniki - charakterystyki } \\
\text { niezawodności }\end{array}$} & 35 & 29,17 & {$[10,13,17,25,36,40,47,50,56,60,64, \underline{68}, 69,70,71,72,73$, } \\
\hline & $\underline{6}$ & $\underline{31,58}$ & $\underline{119}, \underline{120}, \underline{121}, 122]$ \\
\hline Postulaty niezawodnościowe & 21 & 17,50 & {$[3,11,43,46,47,48,54,57,59,62,63,68,69,87,92,96,98$,} \\
\hline & $\underline{5}$ & $\underline{26,32}$ & $\underline{99}, 110, \underline{114}, \underline{120}]$ \\
\hline Inne & 11 & 9,17 & [2 513385279839093941201 \\
\hline & 1 & 5,26 & 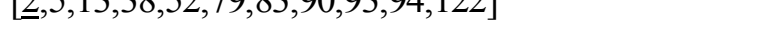 \\
\hline
\end{tabular}




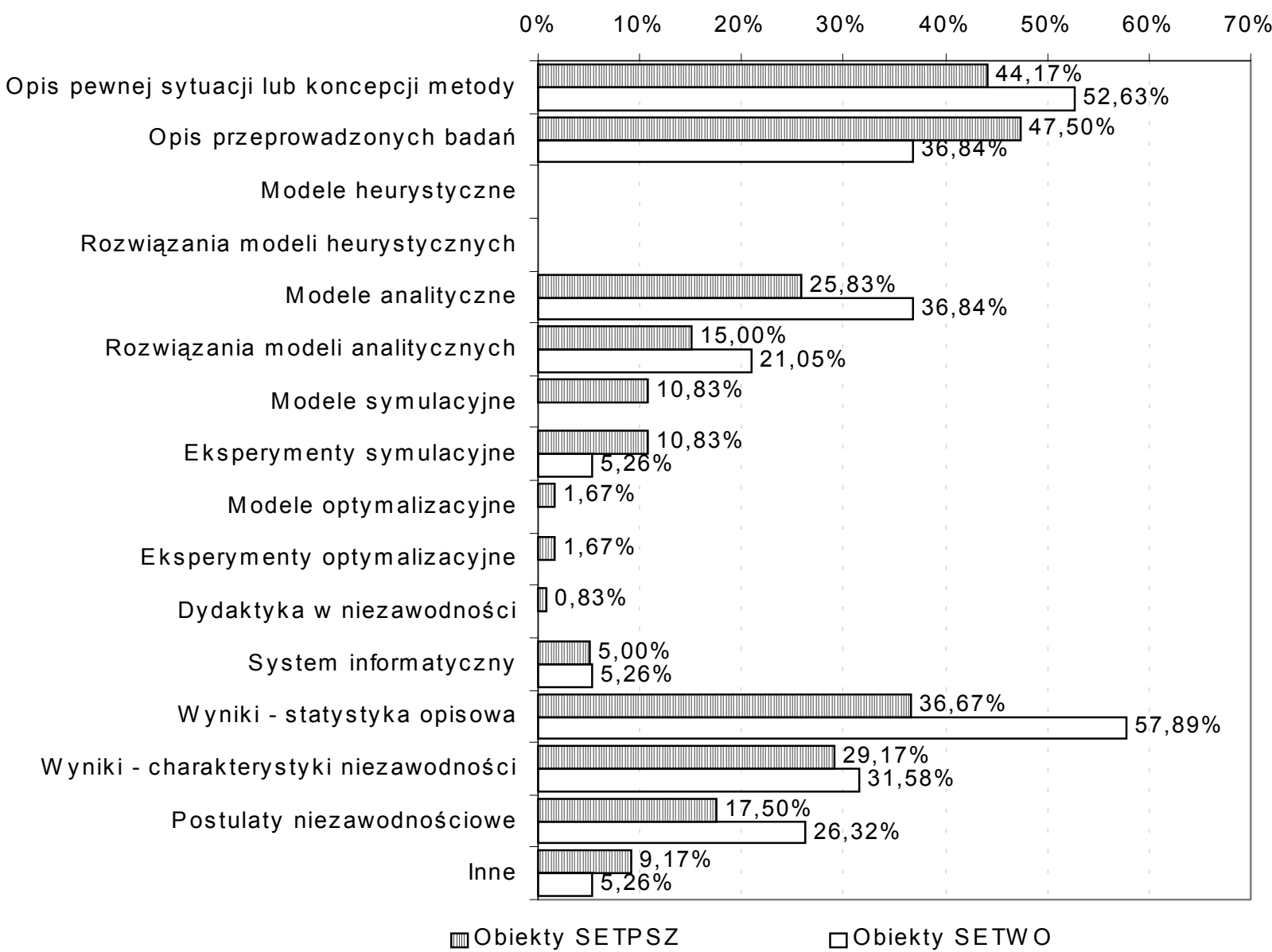

Rys. 7. Histogramy oceny treści prac poświęconych problematyce niezawodności obiektów systemu eksploatacji technicznej pojazdów szynowych

Spośród prac zwiazzanych z systemem eksploatacji technicznej pojazdów szynowych największą liczbę $(47,50 \%)$ stanowią te, w których autorzy przedstawiają opis przeprowadzonych badań.

Wyniki badań przedstawiane są najczęściej $(36,67 \%)$ z wykorzystaniem statystyki opisowej (np. histogram częstości uszkodzeń, średnia liczba uszkodzeń itp.). W pewnej części prac $(29,17 \%)$ autorzy prezentują wyniki w postaci charakterystyk niezawodnościowych.

W niewielkiej liczbie prac (17,50\%) dokonano opisu sytuacji eksploatacyjnych i na tej podstawie stawiano różne postulaty niezawodnościowe. Znaczną część prac $(44,17 \%)$ poświęcono opisowi pewnej sytuacji lub koncepcji metody.

Modele analityczne budowane są w 25,83\% prac, zaś ich rozwiązania pojawiają się tylko w $15,00 \%$ prac. Inaczej przedstawia się problem w przypadku modeli symulacyjnych. Modele takie pojawiają się w 10,83\% prac. Uzupełniane są one zawsze przykładowymi eksperymentami symulacyjnymi ilustrującymi możliwości aplikacyjne modeli.

Wśród prac związanych $\mathrm{z}$ wagonami osobowymi największą liczbę $(57,89 \%)$ stanowią te, w których autorzy przedstawiają wyniki, wykorzystując narzędzia statystyki opisowej. Wyniki w postaci charakterystyk niezawodnościowych prezentowane są w 31,58\% prac. Znaczna część prac $52,63 \%$ poświęcona jest opisowi pewnej sytuacji lub koncepcji metody, natomiast opis przeprowadzonych badań zawarto w 36,84\% prac. Modele analityczne budowane sa w $36,84 \%$ prac zaś ich rozwiązania pojawiają się w $21,05 \%$ pozycji literaturowych poddanych analizie.
Wśród prac poświęconych wagonom osobowym nie pojawiaja się prace związane $\mathrm{z}$ budowaniem modeli symulacyjnych i optymalizacyjnych. W $26,32 \%$ prac stawiano tylko różne postulaty niezawodnościowe.

\section{3. $O$ autorach prac}

Jako autorzy lub współautorzy 120 prac poświęconych niezawodności obiektów systemu eksploatacji technicznej pojazdów szynowych wystęują 52 osoby. W 28 przypadkach (tj. 53,85\%) autorzy brali udział $\mathrm{w}$ przygotowaniu tylko jednego artykułu tzn., że ich zainteresowanie tą tematyką było incydentalne. W przypadku 19 artykułów z zakresu niezawodności wagonów osobowych jako autorzy lub współautorzy występuje 12 osób, wśród których aż 9ciu (tj. 75\%) brało udział w przygotowaniu tylko jednej pracy.

Pełny rozkład liczby artykułów napisanych przez uwzględnionych $\mathrm{w}$ analizie autorów pokazano $\mathrm{w}$ tabelach 4 i 5 . Z tabeli 4 wynika m.in., że w badanym okresie tylko 6-ciu autorów (Andrzej Fórmaniak - 7, Adam Kadziński-19, Jerzy Magiera-8, Józef Marciniak-14, Zbigniew Matuszak - 10, Wiesław Wójcicki - 10) opublikowało co najmniej 7 prac poświęconych zagadnieniom niezawodności obiektów systemu eksploatacji technicznej pojazdów szynowych. Natomiast wśród autorów, którzy poruszają zagadnienia związane $\mathrm{z}$ niezawodnością wagonów osobowych (tabela 5) tylko trzech (Józef Marciniak 2, Mikołaj Moczarski - 2, Wiesław Wójcicki - 9) opublikowało więcej niż jedną pracę. 
Rozkład liczby prac związanych z niezawodnością obiektów SETPSZ opublikowanych przez uwzględnionych w a)

\begin{tabular}{|c|c|c|}
\hline \multirow{2}{*}{$\begin{array}{c}\text { Liczba prac } \\
\text { opublikowanych } \\
\text { przez autora }\end{array}$} & \multicolumn{2}{|c|}{ Autorzy lub współautorzy } \\
\hline & Liczba & {$[\%]$} \\
\hline 1 & 28 & 53,85 \\
\hline 2 & 6 & 11,54 \\
\hline 3 & 5 & 9,62 \\
\hline 4 & 5 & 9,62 \\
\hline 5 & 1 & 1,92 \\
\hline 6 & 1 & 1,92 \\
\hline 7 & 1 & 1,92 \\
\hline 8 & 1 & 1,92 \\
\hline 9 & 0 & 0,00 \\
\hline 10 & 2 & 3,85 \\
\hline 11 & 0 & 0,00 \\
\hline 12 & 0 & 0,00 \\
\hline 13 & 0 & 0,00 \\
\hline 14 & 1 & 1,92 \\
\hline 15 & 0 & 0,00 \\
\hline 16 & 0 & 0,00 \\
\hline 17 & 0 & 0,00 \\
\hline 18 & 0 & 0,00 \\
\hline 19 & 1 & 1,92 \\
\hline Ogółem & 52 & 100,00 \\
\hline
\end{tabular}

b)

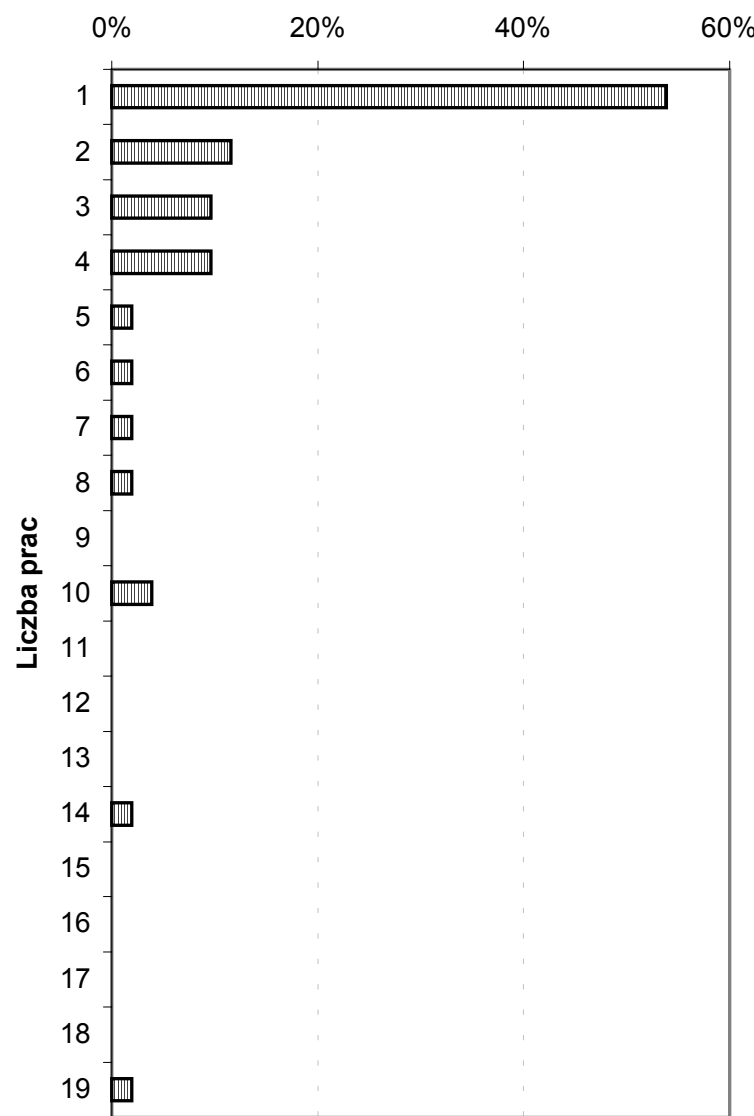

Rozkład liczby prac związanych z niezawodnością obiektów SETWO i opublikowanych przez uwzględnionych w

a)

\begin{tabular}{|c|c|c|}
\hline \multirow{2}{*}{$\begin{array}{c}\text { Liczba prac } \\
\text { opublikowanych } \\
\text { przez autora }\end{array}$} & \multicolumn{3}{|c|}{ Autorzy lub współautorzy } \\
\cline { 2 - 3 } & Liczba & {$[\%]$} \\
\hline 1 & 9 & 75,00 \\
\hline 2 & 2 & 16,67 \\
\hline 3 & 0 & 0,00 \\
\hline 4 & 0 & 0,00 \\
\hline 5 & 0 & 0,00 \\
\hline 6 & 0 & 0,00 \\
\hline 7 & 0 & 0,00 \\
\hline 8 & 0 & 0,00 \\
\hline 9 & 1 & 8,33 \\
\hline Ogółem & 12 & 100,00 \\
\hline
\end{tabular}

Wśród autorów zajmujących się problemami niezawodności obiektów systemu eksploatacji technicznej pojazdów szynowych $56,49 \%$ osób zatrudnionych było na wyższych uczelniach, natomiast $23,38 \%$ autorów prac pracowało w ośrodkach badawczych. W przypadku wagonów osobowych większość autorów (72,73\%) zatrudnionych było w ośrodkach badawczych, a w szkołach wyższych pracowało $18,18 \%$. Problem zatrudnienia autorów prac zilustrowano histogramem na rys. 8 a. b)

Tabela 5

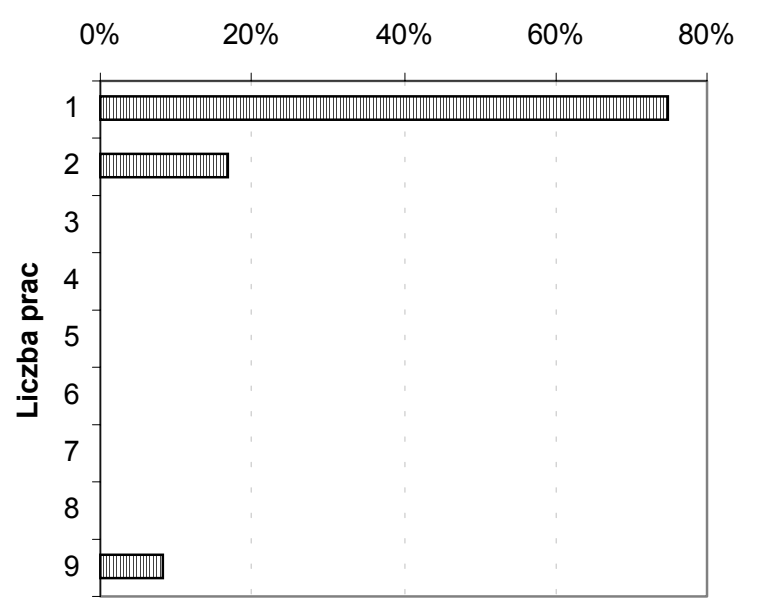

Autorzy artykułów poddanych analizie w chwili ich wydrukowania byli osobami o różnym statusie naukowym i zawodowym. Po kwalifikacji autorów artykułów do następujących grup tworzonych według kryterium statusu naukowego i zawodowego:

- grupa I - prof. dr hab. inż.; dr hab. inż.; doc.,

- grupa II - dr inż.; dr,

- grupa III - mgr inż.; mgr; inż.,

- grupa IV - technik i inni, 
uzyskano empiryczny rozkład prawdopodobieństwa

przedstawiony na rys. 8 b.

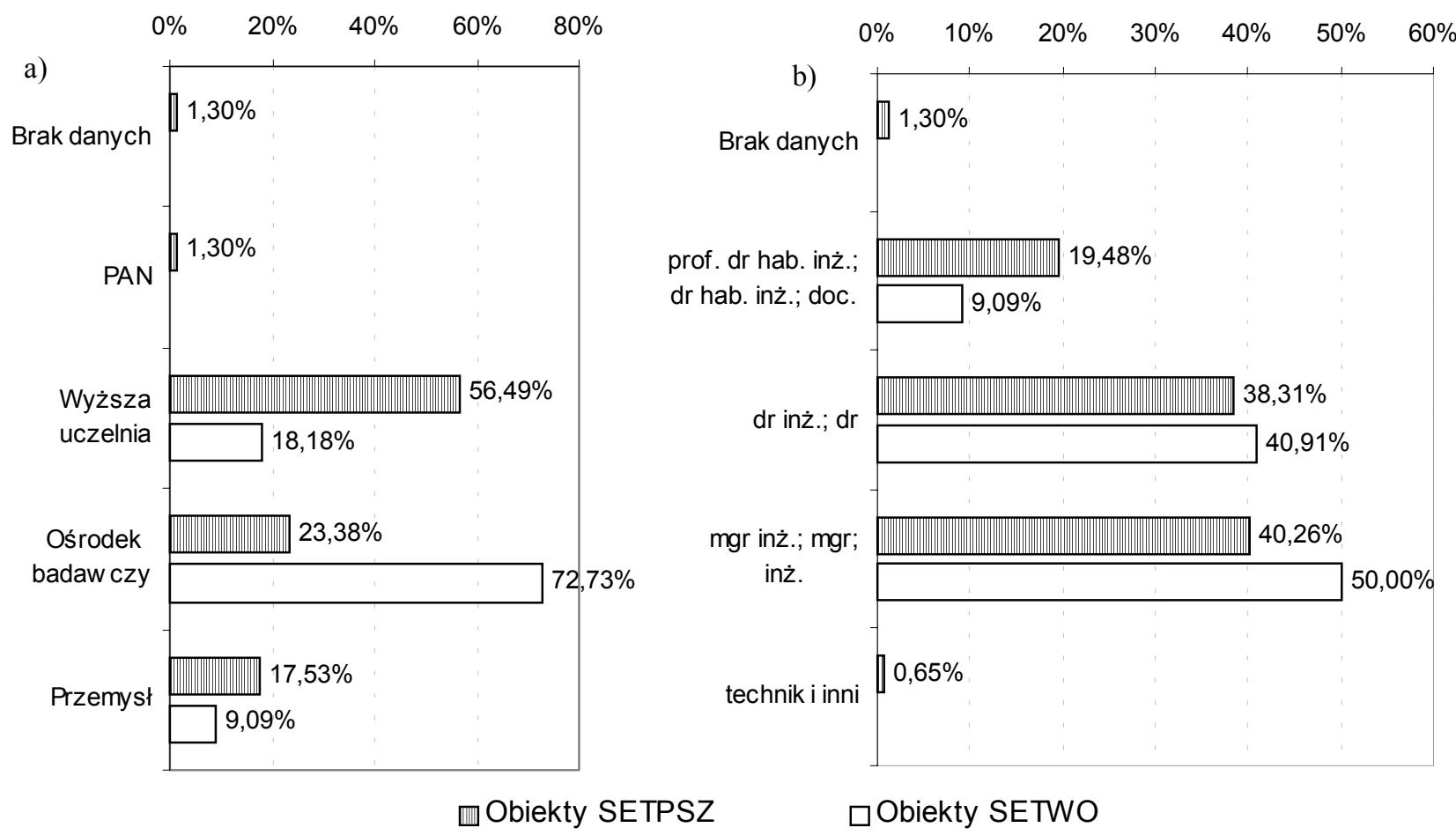

Rys. 8. Prezentacja autorów prac poświęconych problemom badań niezawodnościowych w obszarze systemu eksploatacji technicznej pojazdów szynowych według miejsca ich zatrudnienia (a) i przynależności do grup kwalifikacji zawodowych (b) w chwili publikacji prac

\section{Uwagi końcowe}

W pracach $[29,33]$ autorzy niniejszego opracowania podejmowali już zadania oceny stanu zainteresowań problematyką niezawodności w obszarze systemu transportu kolejowego. Horyzont czasowy tych badań sięgał roku 1998. Wskazano wtedy na fakt, że $75 \%$ prac mieściło się $\mathrm{w}$ obszarze systemu eksploatacji technicznej pojazdów szynowych. W badaniach, których wyniki zaprezentowano $\mathrm{w}$ niniejszym opracowaniu, proporcja ta jest nadal obowiązująca.

Materiały źródłowe wskazują, że coraz więcej prac poświęcanych jest etapowi eksploatacji pojazdów szynowych lub funkcjonowania ich systemów. Do roku 1998 było to $54,7 \%$ prac $[29,33]$, zaś obecnie ten okres życia obiektów/systemów jest reprezentowany w 74,17\% prac.

Zainteresowanie problematyką niezawodności w obszarze systemu eksploatacji technicznej pojazdów szynowych ma charakter głównie ocenowy (pasywny). Taki stan rzeczy wskazuje, że w Polsce są ludzie, którzy potrafią m.in. prowadzić badania niezawodnościowe obiektów systemu eksploatacji technicznej pojazdów szynowych i na podstawie ich wyników wyznaczać charakterystyki niezawodnościowe tych obiektów. Istnieje jednak mało prac, w których pokazywanoby sposoby wykorzystywania wiedzy o niezawodności obiektów w procesach ich projektowania (jest to szczególnie trudne) oraz planowania eksploatacji (w tej dziedzinie pewne osiągnięcia są widoczne). Nie ma jednak alternatywy dla takich działań.

W okresie obejmującym lata $1972 \div 2003$ opublikowano tylko 19 prac poruszających zagadnienia niezawodności w obszarze systemu eksploatacji technicznej wagonów osobowych. Najwięcej z nich powstało w latach
$1979 \div 1980$ a ich autorem był W. Wójcicki. Ostatnie prace na ten temat opublikowano w latach $1995 \div 1996$. W przeprowadzonych badaniach napotkano tylko jeden artykuł na temat niezawodności wagonów osobowych przeznaczonych do jazdy z prędkością $200 \mathrm{~km} / \mathrm{h}$.

Niniejsze opracowanie - w głównym zamyśle jego autorów - jest podsumowaniem aktualnego stanu badań i materiałem wyjściowym do studiowania zagadnień niezawodności obiektów systemu eksploatacji technicznej pojazdów szynowych.

\section{Literatura}

[1] Babet M., Warunki pracy, charakterystyka eksploata-cyjna a niezawodność doładowanych trakcyjnych silników spalinowych, Trakcja i Wagony, nr 9, 1990, s. $163 \div 165$.

[2] Chmiel J., Model odnowy i optymalny czas pracy elektronicznego termostatu wagonowego typu ETW-

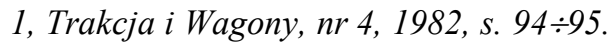

[3] Fórmaniak A., Metoda określenia niezawodności elementów układu napędowego szynowego pojazdu trakcyjnego na etapie projektowania, Zeszyty $\mathrm{Na}$ ukowe Politechniki Poznańskiej seria MRiP, ze-

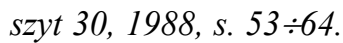

[4] Fórmaniak A., O możliwości określenia niezawodności obiektu na etapie projektowania, w: Materiaty V Konferencji Naukowej „Pojazdy szynowe”, War-

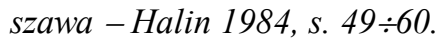


[5] Fórmaniak A., Problemy zapewnienia niezawodności na etapie projektowania, w: Materiaty VI Konferencji Naukowej „Pojazdy szynowe”, Wrocław - Radków 1986, Prace Naukowe IKiEM Politechniki Wrocławskiej, seria Konferencje, $n r$ 11, s. 295: 299.

[6] Fórmaniak A., Szacowanie niezawodności taboru kolejowego na etapie projektowania, Zagadnienia Eksploatacji Maszyn, kwartalnik PAN, zeszyt 4, 1988, s. 503-512.

[7] Fórmaniak A., Kadziński A., Projektowanie pojazdów szynowych i ich eksploatacji z uwzględnieniem niezawodności, Problemy Kolejnictwa, zeszyt 106, 1989, s. $42 \div 77$.

[8] Fórmaniak A., Kadziński A., Komorowski B., Ocena trwałości i niezawodności podwozia lokomotywy ST44, w: Materiaty III Krajowej Konferencji „Pojazdy szynowe”, Poznań 1979, s. 611 615 .

[9] Fórmaniak A., Kasprzak B., Kadziński A., Znaczenie badań niezawodności pojazdów szynowych, Trakcja $i$ Wagony, $n r$ 10, 1984, s. $273 \div 276$.

[10] Gałaź R., Nowakowski T., Projektowanie zderzaków z uwzględnieniem niezawodnościowej analizy struktury, w: Materiaty V Konferencji Naukowej „Pojazdy szynowe", Warszawa - Halin 1984, s. 61 $\div 72$.

[11] Grabarek I., Uwarunkowania ergonomiczne niezawodności pracy maszynisty pojazdu trakcyjnego, Technika Transportu Szynowego, nr 5, 1998, s. 25.

[12] Gronowicz J., Kadziński A., Lukasiewicz Z., Stan badań niezawodności lokomotyw spalinowych eksploatowanych przez PKP, Trakcja $i$ Wagony, nr 12, 1983, s. $333 \div 335$.

[13] Gronowicz J., Kadziński A., Lukasiewicz Z., Stan badań nie-zawodności lokomotyw spalinowych eksploatowanych w PKP, w: Materiaty Sympozjum „Problemy niezawodności transportu”, Kielce - Cedzyna 1983, s. 73 $\div 79$.

[14] Gronowicz J., Łukasiewicz Z., Tomaszewski F., Badania trwałości i niezawodności silnika spalinowego lokomotywy ST44, w: Materiaty III Krajowej Konferencji „Pojazdy szynowe”, Poznań 1979, s. $605 \div 610$

[15] Guzowski S., Wplyw zużycia fretting na trwałość $i$ niezawodność osi zestawów kołowych, w: Materialy XI Konferencji Naukowej „Pojazdy szynowe”, t. 2,

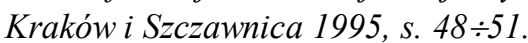

[16] Guzowski S., Wpływ zużycia fretting $w$ elementach pojazdów szynowych na niezawodność i bezpieczeństwo pojazdu w procesie eksploatacji, w: Materiaty VI Konferencji Naukowej „Problemy niezawodności transportu”, t. 1, Ustroń-Jaszowiec 1997, s. 137\% 144.

[17] Guzowski S., Piec P., Analiza niezawodności wagonu towarowego, w: Materiaty I Krajowej Konferencji „Pojazdy szynowe”, Kraków - Zawoja 1973, s. $479 \div 490$.

[18] Jaźwiński J., Niezdatność techniczna wagonów osobowych ze względu na aparaturę elektryczna, Pojaz-

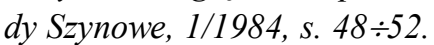

[19] Jedynak M., Wptyw temperatury otoczenia na intensywność niesprawności wybranych podzespołów wagonów typu 401Zb, Zagadnienia Eksploatacji Maszyn, kwartalnik PAN, zeszyt 3, 1974, s. 365 $\div 375$.
[20] Kadziński A., Gotowość systemu eksploatacji lokomotyw spalinowych, w: Materiaty Sympozjum „Problemy niezawodności transportu”, Kielce - Cedzyna 1983, s. 107 $\div 115$.

[21] Kadziński A., Klasa sześciostanowych niezawodnościowych markowskich modeli pojazdów szynowych,

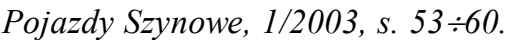

[22] Kadziński A., Modele niezawodnościowe wagonów osobowych i ich systemów eksploatacji, Zeszyty $\mathrm{Na}$ ukowe Politechniki Poznańskiej seria MRiP, zeszyt 43, 1995, s. $23 \div 38$.

[23] Kadziński A., Nauczanie niezawodności pojazdów szynowych wspomagane komputerowo, w: Materiaty VIII Konferencji Naukowej „Pojazdy szynowe”,

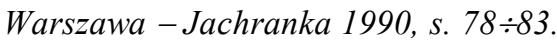

[24] Kadziński A., O niezawodności systemu eksploatacji szynowych pojazdów trakcyjnych, w: Materiaty III Konferencji Naukowej „Problemy niezawodności transportu”, Ustroń - Jaszowiec 1986, s. 161 $\div 171$.

[25] Kadziński A., Ocena realizacji cykli obstugowych liniowych lokomotyw spalinowych eksploatowanych w PKP, w: Materiaty VII Konferencji Naukowej „Pojazdy szynowe”, Rydzyna 1988, Zeszyty Naukowe Politechniki Poznańskiej, Maszyny Robocze i Pojazdy, 1988, nr 31, s. 189 202 .

[26] Kadziński A., Planowanie eksploatacji obiektów technicznych na etapie projektowania z uwzględnieniem ich niezawodności poczatkowej, w: Materiaty XIX Zimowej Szkoty Niezawodności, Szczyrk 1991, s. $71 \div 84$.

[27] Kadziński A., Prognozowanie liczby uszkodzeń lokomotyw spalinowych, w: Materiaty IV Krajowej Konferencji „Pojazdy szynowe”, Kraków - Janowice 1983, s. 426 436 .

[28] Kadziński A., Symulacja komputerowa procesu obstugiwania wagonów towarowych $w$ wagonowniach pracujacych metoda stanowiskowa, w: Materiaty IX Krajowej Konferencji „Pojazdy szynowe”, Kraków

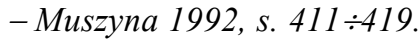

[29] Kadziński A., Stan badań niezawodności w transporcie kolejowym - część 1, Zeszyty Naukowe Politech-

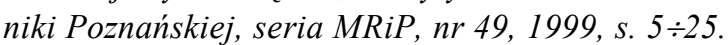

[30] Kadziński A., Szacowanie trwałości części sprężarek trakcyjnych V2P-215, Trakcja i Wagony, nr 2, 1985, s. $36 \div 38$

[31] Kadziński A., Wdrażanie niezawodności do planowania eksploatacji pojazdów trakcyjnych, Zagadnienia Eksploatacji Maszyn, kwartalnik PAN, zeszyt 1, 1992, s. 47 $\div 56$.

[32] Kadziński A., Wielostanowe modele lokomotyw spalinowych $i$ ich systemów eksploatacji, w: Materiaty X Konferencji Naukowej „Pojazdy szynowe”, t. 2,

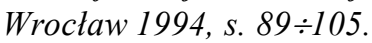

[33] Kadziński A., Kowalski M., Stan badań niezawodności $w$ transporcie kolejowym - część 2, Zeszyty Naukowe Politechniki Poznańskiej, seria MRiP, nr 51, 2000, s. $5 \div 23$.

[34] Kadziński A., Woźniak A., Model diagnostycznoniezawodnościowo-bezpieczeństwowy systemu eksploatacji lokomotyw spalinowych, Pojazdy Szynowe, 3/2000, s. $47 \div 52$. 
[35] Kadziński A., Woźniak A., Model systemu obstugiwania wagonowni pracujacej metoda stanowiskowa, w: Materiaty V Konferencji Naukowej „Problemy

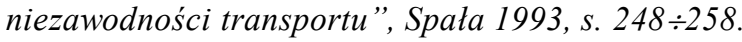

[36] Kasprzak B., Tomaszewski F., Badania niezawodności kolejowych silników spalinowych, Zeszyty $\mathrm{Na}$ ukowe Politechniki Poznańskiej, seria MRiP, nr 35, 1990, s. $87 \div 99$.

[37] Klimowicz S., Markiewicz Z., Analiza awaryjności wagonów osobowych, w: Materiaty VI Konferencji Naukowej „Pojazdy szynowe”, Wrocław-Radków 1986, Prace Naukowe IKiEM Politechniki Wrocław-

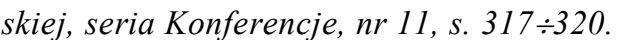

[38] Kos S., Michalak J., Podwyższenie trwatości i niezawodności wagonów cystern do przewozu płynnej siarki, w: Materiały I Krajowej Konferencji "Pojazdy Szynowe", Kraków - Zawoja 1973, s. 509 $\div 522$.

[39] Krzyszkowski A., Analiza uszkodzeń silników trakcyjnych taboru elektrycznego Lokomotywowni pozaklasowej w Skarżysku-Kamiennej w 1990 roku, w: Materiaty IX Konferencji Naukowej „Pojazdy szynowe”, Kraków - Muszyna 1992, s. 447:454.

[40] Kubala I., Wplyw zużycia komutatorów na niezawodność silników trakcyjnych $w$ okresie pomiędzy naprawami, w: Materiaty II Krajowej Konferencji „Pojazdy szynowe”, Kraków - Piwniczna 1977, t. 2, s. $152 \div 165$.

[41] Lewandowski P., Raczyński J., Styczniki trakcyjne nowej generacji o zwiększonej niezawodności, Tech-

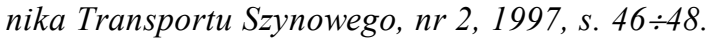

[42] Lisowski Z., Badania eksploatacyjne pojazdu szynowego na poduszce magnetycznej kolei RFN. Problem niezawodności, w: Materiały V Konferencji Naukowej „Pojazdy szynowe”, Warszawa - Halin 1984, s. $166 \div 175$.

[43] Lisowski Z., Metodyka utrzymania w ruchu pojazdów szynowych, w: Materiały XIII Zimowej Szkoty

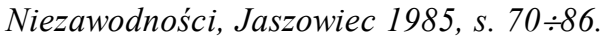

[44] Lisowski Z., Modele niezawodności Boole'a i Markowa z uwzględnieniem wpływu człowieka w praktyce eksploatacyjnej pojazdów szynowych, w: Materiaty VI Konferencji Naukowej „Pojazdy szynowe”, Wrocław-Radków 1986, Prace Naukowe IKiEM Politechniki Wrocławskiej, seria Konferencje, $n r$ 11, s. $219 \div 226$.

[45] Lisowski Z., Strategia optymalizacji niezawodności pojazdów szynowych, Pojazdy Szynowe, 4/1976, s. $27 \div 29$

[46] Lisowski Z., Zastosowanie teorii Gumbela do oceny niezawodności pojazdów szynowych, Zagadnienia Tarcia, Zuzycia i Smarowania, kwartalnik PAN, zeszyt 12, 1972, s. $61 \div 69$.

[47] Lisowski Z., Piec P., Określenie trwałości i niezawodności zestawów kołowych lokomotyw elektrycznych, w: Materiaty III Krajowej Konferencji „Po-

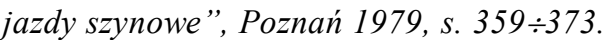

[48] Magiera J., Eksploatacja kolejowych pojazdów szynowych. Jakość, niezawodność i bezpieczeństwo systemu, w: Materiaty VI Konferencji Naukowej „Problemy niezawodności transportu”, t. 2, Ustroń

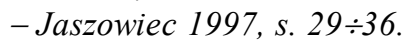

[49] Magiera J., Niezawodność i jakość w pojazdach szynowych, w: Materiaty XXVI Zimowej Szkoty Niezawodności, Szczyrk 1998, s. 109 $\div 113$.
[50] Magiera J., Niezawodność pojazdów trakcyjnych $w$ świetle oceny kosztów ich eksploatacji, Zagadnienia Eksploatacji Maszyn, kwartalnik PAN, zeszyt 3, 1984, s. $485 \div 491$.

[51] Magiera J., Niezawodność pojazdów trakcyjnych $w$ świetle oceny kosztów ich eksploatacji, w: Materiaty V Konferencji Naukowej „Pojazdy szynowe”, Warszawa - Halin 1984, s. $263 \div 275$.

[52] Magiera J., Prognoza niezawodności pojazdów szynowych - metody oceny $i$ analiza trendowa, w: Materiały XXV Zimowej Szkoły Niezawodności, Szczyrk 1997, s. $124 \div 130$.

[53] Magiera J., Techniczno-ekonomiczne wskaźniki niezawodności pojazdów szynowych, w: Materiaty IV Krajowej Konferencji „Pojazdy szynowe”, Kraków - Janowice 1983, s. 339 $\div 345$.

[54] Magiera J., Oprzędkiewicz J., Monitorowanie niezawodności pojazdów szynowych, w: Materiaty IX Krajowej Konferencji „Pojazdy szynowe”, Kraków

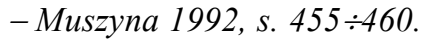

[55] Marciniak J., Badania diagnostyczne pojazdów szynowych $w$ czasie realnym, w: Materiaty IV Krajowej Konferencji „Pojazdy szynowe”, Kraków - Janowice 1983, s. 353 $\div 363$.

[56] Marciniak J., Badania niezawodności wybranych typów elektrycznych maszyn trakcyjnych, w: Materiaty IV Konferencji Naukowej „Problemy nieza-

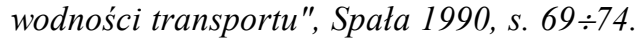

[57] Marciniak J., Kształtowanie niezawodności kolejowych pojazdów szynowych na etapie projektowania $i$ wytwarzania, Zagadnienia Eksploatacji Maszyn, kwartalnik PAN, zeszyt 4, 1991, s. 487 $\div 498$.

[58] Marciniak J., Metodyka utrzymania w ruchu kolejowych pojazdów szynowych PKP, w: Materiaty XIII Zimowej Szkoły Niezawodności, Jaszowiec 1985, s. $87 \div 106$.

[59] Marciniak J., Modele niezawodności funkcjonalnej pojazdów szynowych, Trakcja i Wagony, nr 9, 1980, s. $225 \div 229$.

[60] Marciniak J., Niezawodność kolejowych pojazdów szynowych, Przeglad Kolejowy, zeszyt 9, 1997, s. 6־ 10.

[61] Marciniak J., Niezawodność wyposażenia elektrycznego kolejowych pojazdów szynowych, Przeglad Kolejowy, zeszyt 10, 1996, s. $1 \div 6$.

[62] Marciniak J., Problemy zwiększenia niezawodności maszyn trakcyjnych elektrycznych pojazdów PKP, Trakcja i Wagony, nr 7, 1989, s. 129 $\div 132$.

[63] Marciniak J., Restrukturyzacja procesów eksploatacji pojazdów szynowych PKP, w: Materiaty IX Krajowej Konferencji „Pojazdy szynowe”, Kraków-Muszyna 1992, s. $461 \div 465$.

[64] Marciniak J., Wybrane problemy utrzymania zdatności pojazdów szynowych PKP, w: Materiaty VI Konferencji Naukowej „Pojazdy szynowe”, Wroclaw - Radków 1986, Prace Naukowe IKiEM Politechniki Wroctawskiej, seria Konferencje, nr 11, s. $241 \div 248$.

[65] Marciniak J., Zawodność eksploatacyjna elektrycznych maszyn trakcyjnych i badania przyczyn zawodności, w: Materiaty VII Konferencji Naukowej „Pojazdy szynowe”, Rydzyna 1988, t. Badania pojazdów szynowych, s. $81 \div 86$. 
[66] MarciniakJ., Zawodność eksploatacyjna elektrycznych maszyn trakcyjnych PKP, Trakcja i Wagony, nr 8, 1988, s. $164 \div 167$.

[67] Marciniak J., Krzyszkowski A., Badania w zakresie zwiększania niezawodności uzwojeń silnika trakcyjnego LK 450, w: Materiaty X Krajowej Konferencji

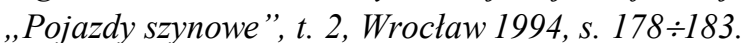

[68] Marciniak J., Biliński J., Krawczyk F., Nezawodność wagonów pasażerskich nowej konstrukcji, Problemy Kolejnictwa, zeszyt 116, 1994, s. 37 $\div 54$.

[69] Matuszak K., Struktura funkcjonalna jako zbiór informacji o obciażeniu elementów maszyny do remontu torów, w: Materiaty XII Konferencji Nauko-

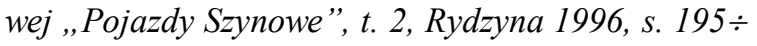
200.

[70] Matuszak Z., Analiza ilości załaczeń i uszkodzeń styczników obwodu rozruchu oporowego i jazdy lokomotyw elektrycznych, w: Materiaty VII Konferencji Naukowej „Pojazdy szynowe”, Rydzyna 1988, t. Eksploatacja pojazdów szynowych, s. 34 $\div 49$.

[71] Matuszak Z., Niezawodność układu styczników rozruchowych lokomotywy elektrycznej jako uktadu o zmiennej strukturze funkcjonalnej, Problemy Kolejnictwa, zeszyt 111, 1992, s. $58 \div 71$.

[72] Matuszak Z., Obserwacja niezawodności elektrycznych pojazdów trakcyjnych $w$ lokomotywowniach,

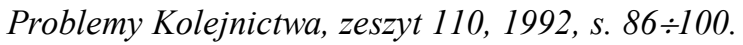

[73] Matuszak Z., Szacowanie niezawodności zmiennych struktur funkcjonalnych na przykładzie układu styczników rozruchowych $w$ obwodzie głównym lokomotyw elektrycznych, w: Materiaty VIII Konferencji Naukowej „Pojazdy szynowe”, Warszawa - Jachranka 1990, s. $182 \div 188$.

[74] Matuszak Z., Uszkodzenia i wybrane charakterystyki niezawodnościowe obwodu pomocniczych maszyn lokomotyw elektrycznych ET-22, Trakcja i Wagony,

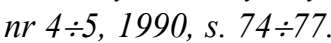

[75] Matuszak Z., Uszkodzenia i wybrane charakterystyki niezawodnościowe obwodu głównego lokomotyw elektrycznych serii ET-22, Trakcja i Wagony, nr 1/2, 1990, s. $6 \div 10$.

[76] Matuszak Z., Uszkodzenia i wybrane charakterystyki niezawodnościowe układu pneumatycznego lokomo-

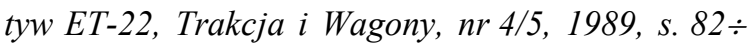
85 .

[77] Matuszak Z., Wptyw miejsca i rodzaju uszkodzenia lokomotywy elektrycznej na zablokowanie szlaku kolejowego, w: Materiaty $V$ Konferencji Naukowej „Problemy niezawodności transportu”, Spała 1993, s. $267 \div 274$.

[78] Matuszak K., Matuszak Z., Zastosowanie zamkniętego systemu obstugi do modelu eksploatacji lokomotyw elektrycznych serii ET22, w: Materiaty VI Konferencji Naukowej „Pojazdy szynowe”, Wrocław-Radków 1986, Prace Naukowe IKiEM Politechniki Wrocławskiej, seria Konferencje, nr 11, s. $269 \div 278$.

[79] Mierzejewski E., Ocena niezawodności eksploatacyjnej pojazdów trakcyjnych PKP w systemie OSTELOK, w: Materiaty IV Konferencji Naukowej „Problemy niezawodności transportu”, Spała 1990, s. $107 \div 114$
[80] Mierzejewski E., Problemy poprawy stanu technicznego wagonów towarowych na PKP, w: Materiaty IV Krajowej Konferencji „Pojazdy szynowe”, Kra-

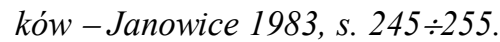

[81] Mierzejewski E., Zagadnienia niezawodności eksploatacyjnej pojazdów trakcyjnych PKP w systemie OSTELOK, w: Materiaty VII Konferencji Naukowej „Pojazdy szynowe”, Rydzyna 1988, $t$. Eksploatacja pojazdów szynowych, s. $51 \div 64$.

[82] Mierzejewski E., Zagadnienie niezawodności eksploatacyjnej pojazdów trakcyjnych PKP w systemie „Ostelok”, Trakcja i Wagony, nr 3, 1989, s. $69 \div 71$.

[83] Młynarski S., Oprzędkiewicz J., Modelowanie rozmyte w niezawodności pojazdów szynowych, w: Materiały X Krajowej Konferencji „Pojazdy szynowe”, t. 2, Wroctaw 1994, s. $201 \div 217$.

[84] Młynarski S., Oprzędkiewicz J., Zastosowanie adaptacyjnych metod prognozowania niezawodności $w$ eksploatacji pojazdów szynowych, Pojazdy Szynowe,

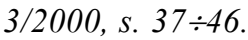

[85] Młyńczak M., Nowakowski T., Ocena niezawodności odbieraka pradu, w: Materiaty III Krajowej Konferencji „Pojazdy szynowe”, Poznań 1979, s. 320\% 324.

[86] Moczarski M., Nowe metody obstugiwania pojazdów szynowych cz. 1, Technika Transportu Szynowego, nr 8, 1996, s. $38 \div 43$.

[87] Moczarski M., Nowe metody obstugiwania pojazdów szynowych cz. 2, Technika Transportu Szynowego,

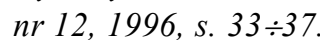

[88] Moczarski M., Obstugiwanie taboru kolejowego czy potrzebne sq zmiany?, Technika Transportu Szynowego, $n$ r 8-9, 1995, s. $44 \div 50$.

[89] Moczarski M., Wymagania dotyczqce konstrukcji wagonów pasażerskich z punktu widzenia obstugiwania, Technika Transportu Szynowego, nr 2, 1996, s. $26 \div 34$.

[90] Monieta J., Analiza uszkodzeń elektrycznych silników trakcyjnych EE 541 oraz silników spalinowych 2112 SSF $i$ a2C22 w Lokomotywowni Szczecin

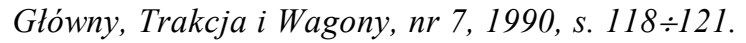

[91] Monieta J., Metoda oceny niezawodności kolejowych silników spalinowych a8C22, Trakcja i Wagony, nr 5/6, 1991, s. $122 \div 126$.

[92] Nowak R., Węzłowe zagadnienia podwyższania niezawodności pojazdów szynowych na etapie prac badawczo-rozwojowych, w: Materiaty III Krajowej Konferencji „Pojazdy szynowe”, Poznań 1979, s. $432 \div 443$.

[93] Nowakowski T., Modelowa ocena niezawodności pojazdów szynowych, w: Materiaty VI Konferencji Naukowej „Pojazdy szynowe”, Wrocław-Radków 1986, Prace Naukowe IKiEM Politechniki Wrocław-

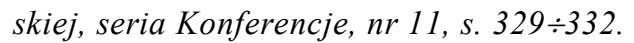

[94] Oprzędkiewicz J., Magiera J., Problematyka niezawodnościowa $w$ pracach Instytutu Pojazdów Szynowych w latach 1971-1996, w: Materiaty XXV Zimowej Szkoły Niezawodności, Szczyrk 1997, s. $158 \div 162$.

[95] Pawlus J., Piotrowski W., Badania zużywania, trwatości i niezawodności kół zębatych przekładni napędowych w pojazdach trakcyjnych PKP, w: 
Materiaty I Krajowej Konferencji „Pojazdy Szynowe", Kraków - Zawoja 1973, s.435 456 .

[96] Piec P., Analiza eksploatacyjna trwałości pojazdów szynowych, w: Materiaty VI Konferencji Naukowej „Problemy niezawodności transportu", t. 2, Ustroń - Jaszowiec 1997, s. $111 \div 118$.

[97] Piec P., Sowa A., Analiza niezawodności pojazdów szynowych z uwzględnieniem struktur połaczeń, w: Materiaty VII Konferencji Naukowej „Pojazdy szynowe”, Rydzyna 1988, Zeszyty Naukowe Politechniki Poznańskiej, Maszyny Robocze i Pojazdy, 1988, nr 31, s. $225 \div 232$.

[98] Plewako S., Wpływ konserwacji silników trakcyjnych na trwałość i niezawodność pojazdów szynowych, w: Materiaty III Krajowej Konferencji „Pojazdy szy-

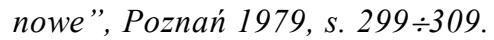

[99] Prażewska M., Prognozowanie niezawodnościowe, w: Materiaty $V$ Konferencji Naukowej „Problemy niezawodności transportu”, Spała 1993, s. 283 295 .

[100] Przerembel S., Relacje systemotwórcze zintegrowanego systemu badań niezawodności pojazdów szynowych, Trakcja i Wagony, nr 9, 1980, s. 229 $\div 231$.

[101] Raczyński J., Awaryjność silników trakcyjnych i przetwornic zespołów trakcyjnych EN57, Technika

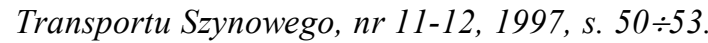

[102] Raczyński J., O systemach utrzymania pojazdów szynowych, Technika Transportu Szynowego, nr 1112, 1995, s. $50 \div 53$.

[103] Raczyński J., Panek J., Awaryjność silników trakcyjnych LK 450 i EE 541-porównania i analizy intensywności uszkodzeń, Trakcja i Wagony, nr 8, 1990, s. $143 \div 146$.

[104] Raczyński J., Szafrański Z., O ewidencji usterek pojazdów szynowych, Technika Transportu Szynowego, $n r$ 4, 1996, s. $43 \div 45$.

[105] Sowa A., Proces napraw bieżacych pojazdów szynowych $w$ ujęciu modelu systemu obstugi masowej,

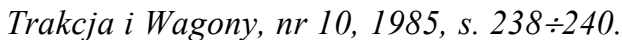

[106] Starowicz W., Zastosowanie strategii odnawiania sekwencyjnego do planowania okresów między kolejnymi naprawami pojazdów trakcyjnych, w: Materiaty III Krajowej Konferencji „Pojazdy szynowe”, Poznań 1979, s. 616 621 .

[107] Śmiałowski J., Analiza uszkodzeń zespołu napędowego lokomotyw serii EU06/07 $w$ aspekcie zwiększania prędkości jazdy, w: Materiaty II Krajowej Konferencji „Pojazdy szynowe”, Kraków-Piwniczna 1977, t. Komunikaty, s. 44 $\div 52$.

[108] Tomaszewski F., System wspomagajacy ocene niezawodności komputerowych systemów sterowania ruchem kolejowym, w: Materiaty I Konferencji Badań i Niezawodności, KONBiN, Szczyrk 2001, t. 3, s. $133 \div 140$.

[109] Tomaszewski F., Wybór zespolu lokomotywy spalinowej do badań diagnostycznych, w: Materiaty IV Konferencji Naukowej „Pojazdy szynowe”, Kraków-Janowice 1983, s. 437:445.
[110] Węclewski S., Optymalizacja utrzymania pojazdów trakcyjnych, w: Materiaty III Krajowej Konferencji

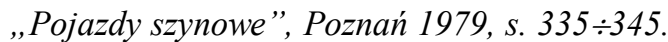

[111] Woźniak A., Matuszak Z., Określenie niezawodności układu styczników $w$ obwodzie rozruchu oporowego $i$ jazdy lokomotywy elektrycznej, w: Materiaty VII Konferencji Naukowej „Pojazdy szynowe”, Rydzyna 1988, Zeszyty Naukowe Politechniki Poznańskiej,

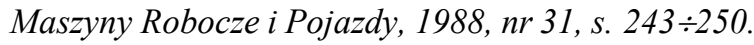

[112] Wójcicki W., Analiza statystyczna wpływu warunków eksploatacji na wykonanie naprawy wagonowej aparatury elektrycznej, Pojazdy Szynowe, 3/1979, s. $46 \div 54$.

[113] Wójcicki W., Analiza statystyczna wspótczynnika czynnego ogrzewania wagonów osobowych, Pojazdy Szynowe, 2/1979, s. 48 $\div 52$.

[114] Wójcicki W., Czas niezawodnego użytkowania elektrycznego wyposażenia wagonów osobowych, Pojazdy Szynowe, 4/1977, s. 33 $\div 39$.

[115] Wójcicki W., Estymacja statystyczna współczynnika technicznego wykorzystania instalacji wagonów

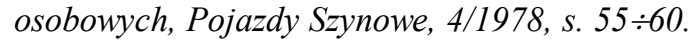

[116] Wójcicki W., Intensywność uszkodzeń elektrycznego wyposażenia wagonów osobowych, Pojazdy Szynowe, 2/1980, s. $55 \div 64$.

[117] Wójcicki W., Niezdatność techniczna wagonów osobowych ze względu na aparaturę elektryczna, Pojazdy Szynowe, 1/1979, s. 48 $\div 52$.

[118] Wójcicki W., Trwatość i niezawodność wagonów towarowych, Trakcja i Wagony, nr 7/8, 1981, s. 202: 208.

[119] Wójcicki W., Trwałość instalacj ielektrycznej wagonów osobowych, Trakcja i Wagony, nr 9, 1980, s. $232 \div 233$.

[120] Wójcicki W., Weryfikacja cyklu obstugi instalacji elektrycznej wagonów osobowych, Trakcja $i$ Wagony, 10/1980, s. $274 \div 283$.

[121] Wójcicki W., Wskaźnik MTBF dla urzqdzeń instalacji elektrycznej wagonów osobowych, w: Materiaty III Krajowej Konferencji „Pojazdy szynowe”, Poznań 1979, s. $539 \div 543$.

[122] Zaorski M., Określenie wartości oczekiwanej E[Tz] zmiennej losowej Tz określajacej czas przebywania w stanie zdatności zespotu urzadzeń pojazdów trakcyjnych od naprawy okresowej do uszkodzenia, w: Materiaty IV Krajowej Konferencji „Pojazdy szynowe", Kraków - Janowice 1983, s. 374 $\div 382$. 